\title{
BioLink
}

Jurnal Biologi Lingkungan, Industri, Kesehatan

\section{TEMPERATURE AND NITRATE CONCENTRATION EFFECT ON THE ABUNDANCE AND GROWTH RATE OF MELOSIRA SP.}

\author{
Nita Rukminasari*, Sharifuddin Bin Andy Omar, \& Muhammad Lukman
}

Aquatic Resources Management Study Program, Faculty of Marine and Fisheries Sciences, Universitas Hasanuddin, Makassar, Indonesia

\begin{abstract}
Microalgae are one of the natural resources that have high potential as a source of biofuels, one of them is the marine microalgae Melosira sp.. The objective of this study was to determine the effect of increasing temperature and nitrate concentration on the abundance, growth rate, biomass, organic C-content and free fatty acids of Melosira sp.. A Completely Randomized Design was used for this experiment with four temperature treatments and three nitrate concentrations treatments in microalgae test planting media. The test microalgae were cultured for 21 days, while the abundance of Melosira sp..was carried out every 3rd day, while for other parameters measurements were made at the end of the experiment. The results showed that the increasing in temperature and nitrate concentration in culture media significantly affected the abundance of Melosira sp.. Meanwhile, the results of statistical analysis showed that the increase in temperature and concentration of culture media did not have a significant effect on biomass except at $30^{\circ} \mathrm{C}$ treatment, the dry weight of Melosira sp. was only significantly different between the nitrate concentrations of $0.0 \mathrm{~g} / \mathrm{L}$ and $0.4 \mathrm{~g} / \mathrm{L}$. For the content of C-organic and free fatty acids generally showed $a$ significant difference between treating temperature and nitrate concentration in the culture media.
\end{abstract}

Keywords: Biofuels; Melosira sp..; Increasing Temperature; Nitrate Concentration; Culture Media

How to Cite: Rukminasari, N., Omar, S.B.A., \& Lukman, M. (2021). Temperature and Nitrate Concentration Effect on The Abundance and Growth Rate of Melosira sp., BioLink: Jurnal Biologi Lingkungan, Industri dan Kesehatan, Vol.7 (2): Hal. 185-194 
Rukminasari, N., Omar, S.B.A., \& Lukman, M. Temperature and Nitrate Concentration Effect on The Abundance and Growth Rate of Melosira $\mathrm{Sp}$

\section{INTRODUCTION}

Currently, countries in the world are experiencing two big problems, namely the energy crisis and global warming. The energy crisis occurs due to the decreasing supply of fuel oil. On the other hand, the need for fuel oil is increasing with the increasing number of world population. Indonesia's energy needs from year to year have increased along with the increasing economic growth and population of Indonesia. The average increase in energy needs each year is 36 million barrels of oil equivalent (BOE) from 2000 to 2014. Meanwhile, non-renewable energy reserves, such as oil, natural gas, and coal are running low. Based on the Strategic Plan (Renstra) of the Ministry of Energy and Mineral Resources for 2015-2019, Indonesia's petroleum reserves are 3,6 billion barrels are expected to be exhausted in the next 13 years (Sa'adah et al., 2017). The price of fuel has skyrocketed and the security conditions of oil-producing countries are very unstable. This situation exacerbates the economic conditions, especially developing countries.

Indonesia is one of the developing countries which has a large enough population and also requires a large amount of fuel oil. Currently, the energy crisis, such as fuel oil (BBM) and electricity, have become a hot issue in Indonesia. The fuel oil crisis has made the public aware that so far Indonesia is very dependent on petroleum. The increasingly limited supply of petroleum has caused the price of fuel to increase rapidly. Currently the oil reserves in Indonesia are only 4.9 billion barrels. With a production rate of 550 million barrels per year, both for consumption for public and industrial needs, it is predicted that in the next five years the oil reserves will run out. Apart from being used as fuel, petroleum is a source of electrical energy. Recently, the need for electrical energy for public and industrial consumption is still sufficient. Meanwhile, the petroleum reserves used for power generation in the next few years will be run out (Susilaningsih et al., 2009).

To overcome the above problems, it has become an urgent need to seek various alternative energy sources in overcoming the serious problem of rising fuel prices in the increasingly uncontrolled world market. In the last two or three years, several countries have taken policies to promote biofuels. Initially, biofuels were seen as the right choice, apart from being an alternative to scarce fuel oil, they were also seen as "more environmentally friendly" or "greener" and campaigned as sustainable energy (Rusastra \& Saliem, 2010).

Biofuel consists of several types, namely: Bioethanol, Biodiesel and Biogas. 
Generally, this alternative energy source comes from plants (biomass). The plants that have the potential to produce biofuel are sugarcane, cassava (cassava), oil palm, jatropha and several types of algae (Govoni, et al, 2006).

Research on the biofuels originating from land plants has been widely carried out, but research on biofuels sourced from algae/microalgae in Indonesia is still rarely carried out and published even though the potential of microalgae to be used as an alternative energy source is very large. Several studies on the potential of microalgae as biofuels have been carried out in developing countries. Found that oilrich microalgae was a promising alternative source of fat for producing biodiesel (Chisti, 2008; Li et al., 2008; Oo et al. 2008; Walker et al., 2005).

Furthermore Rupprecht (2009) examined the potential of the algae Clamydomonas reinhardtii as a biohydrogen producer. (Sialve et al., 2009) examined the sustainability of microalgae as a source of biodiesel (Bondioli et al., 2012) examined the extraction of lipids from Nannochloropsis sp microalgae with methanol and chloroform solvents and found that the use of solvents to produce optimum lipid extracts was mixed with a solvent ratio methanol and chloroform which produced the optimum lipid extract was 2: 3 with an extraction time of 3 hours at $70^{\circ} \mathrm{C}$.

Examined the lipid content of several types of marine cyanobacteria and found that Nostoc sp showed the highest growth rate while Oscillatoria $s p$ had the largest lipid content compared to other types of cyanobacteria (Nostoc sp, Synecococcus $s p$ and Lynbya $s p$ ) with a lipid content of 4.2 mg (Ahmad et al, 2013). Conducted research on the design of the conversion process of microalgae into biofuels as an environmentally friendly technological innovation. Previous studies were more about the lipid content of some microalgae, while research on the free fatty acid content of microalgae was still rarely done, whereas the content of free fatty acids was one of the indicators to assess the biofuel potential of microalgae (Lee et al, 2015). Based on it, this study was conducted. This study aimed to determine the effect of increasing temperature and the advantages and disadvantages of NO3 in culture media on the growth rate, biomass and free fatty acid content of microalgae Melosira sp.. While the focus of study was on the content of organic $\mathrm{C}$ and fatty acids from the tested microalgae.

\section{MATERIALS AND METHODS}

The research was carried out in July September 2017 at the Wet Laboratory, 
Research and Development Center for Coastal Seas and Small Islands, Hasanuddin University. This study used a sustainable algae culture method by manipulating the media. The manipulation of the culture media tried was the manipulation of the temperature of the culture media and manipulation of the nutrient content in the culture media.

\section{Research procedure}

The manipulation of culture media to increase the production of free fatty acids from Melosira sp.. Was tested. The pure culture of Melosira sp.. was obtained from the Research Institute for Brackish Water Cultivation and Extension, Maros. The experimental design of the culture media manipulation used a randomized block design with three factors, namely: duration of culture (days), temperature and nutrients. For the duration of the culture will consist of three treatments, namely: 7 days, 14 days and 21 days for each microalgae Melosira sp.. As for the temperature factor, the treatments tested were: $28^{\circ} \mathrm{C}, 30^{\circ} \mathrm{C}, 32^{\circ} \mathrm{C}$ and $34^{\circ} \mathrm{C}$. The nutrient treatment factors consisted of: no nitrogen, normal nitrate levels and excess nitrate levels. Each factor and treatment consisted of three replications. The variables observed were: 1) algae growth rate, 2) total algae production per unit volume, 3) total free acid glue production per unit volume, 4) total dry weight of algae per unit volume and 5) ratio of dry weight of fat to total dry weight of algae per unit volume.

\section{Calculation of growth rate and biomass of tested microalgae}

The growth rate of the tested microalgae was calculated using the following formula:

$$
\mu=(\ln \mathrm{C} 1-\ln \mathrm{Co}) / \Delta t-1
$$

Note: $\mathrm{C}_{0}$ is the number of test microalgae starting cells (cells mL-1), C1 is the number of test microalgae end cells (cells mL-1), and $\Delta \mathrm{t}$ is the time between two counts (days).

The tested microalgae biomass was measured using the gravimetric method. Microalgae were harvested by filtering using filter paper which has known its weight and rinsing with distilled water. Filter paper and the harvest results were then dried in the oven for 24 hours then weighed. The dry weight of harvested microalgae was obtained from reducing the dry weight of filter paper and microalgae with the dry weight of filter paper (Boussiba et al, 1987).

\section{Measurement of microalgae free fatty acid levels}

Free fatty acid content is calculated using the formula according to (Kertaren, 1986):

$$
\mathrm{ALB}=(25.6 \times \mathrm{N} \times \mathrm{Vt}) / \mathrm{BS}
$$


Note: $\mathrm{N}=$ normality of $\mathrm{KOH}$ which had been standardized, $\mathrm{Vt}=$ volume of $\mathrm{KOH}$ used at the time of titration $(\mathrm{mL})$ and $\mathrm{BS}=$ weight of sample (g).

While the percentage of free fatty acids was calculated using the following formula:

$\% \mathrm{FFA}=(\mathrm{N} \mathrm{KOH} \times \mathrm{BM}$ of palmitic acid $\mathrm{x} \mathrm{V}$.

Titration) / m sample x 100

Note: $\mathrm{N}=$ normality, $\mathrm{V}=$ volume of pentiter substance, $\mathrm{M}=$ weight of sample and BM of palmitic acid $=256$

\section{Microalgae sample analysis procedure}

Measurement of research variables was based on references from Bolling and Fiehn (2005) and Um and Kim (2009), while calculating the total algae product per unit volume using the SRC (Sendwich Rafter Chamber) tool.

\section{Data analysis}

The experimental data were analyzed descriptively and statistically. Statistical analysis was conducted to see the relationship between parameters and analyzed using regression analysis, corrrelation and analysis of variance (ANOVA). Data analysis will use statistical software GrapPad Version 7.

\section{RESULTS AND DISCUSSION}

The Effect of increasing temperature and nitrate concentration on the abundance and growth rate of Melosira sp.
Melosira sp. abundance was counted on day $3,7,9,12,15,18$ and day 21 . While the growth rate was calculated at the end of the experiment (day 21). The results of the calculation of the abundance per three days of culture showed that the abundance of Melosira sp.. varies for each nitrate treatment and temperature (Figure 1). The results of statistical analysis showed that Melosira $s p$. abundance for the counting time of 15,18 and 21 days were significantly different between the nitrate treatment concentrations for the four temperature treatments. The peak of cell abundance generally occured on day 21 and the increasing in nitrate concentration and temperature increased significantly the abundance of Melosira sp.. It is in accordance with previous research on marine micralga species Nannocloropsis sp and Dunaniella sp. which were treated with increasing temperature and nutrient manipulation showed an increasing in cell abundance (Rukminasari, 2013).

The increasing of temperature and nitrate concentration affected significantly the growth rate of Melosira sp. (Figure 2). The growth rate of Melosira sp.. tend to be more higher at $28^{\circ} \mathrm{C}$ for each treatment of nitrate concentrations compared to other temperature treatments. The highest growth rate was found in the treatment of Nitra concentration of $0.20 \mathrm{~g} / \mathrm{L}$ at $30^{\circ} \mathrm{C}$ of 0.24 cells/day, while the lowest growth rate of 0.09 
Rukminasari, N., Omar, S.B.A., \& Lukman, M. Temperature and Nitrate Concentration Effect on The Abundance and Growth Rate of Melosira Sp

cells/day was found in the treatment of $0.0 \mathrm{~g} / \mathrm{L}$

of nitra concentration at temperature

treatment. $34^{\circ} \mathrm{C}$.

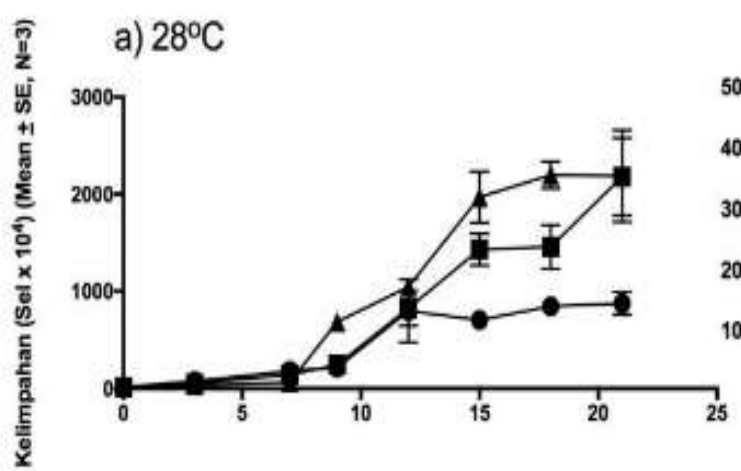

b) $30^{\circ} \mathrm{C}$

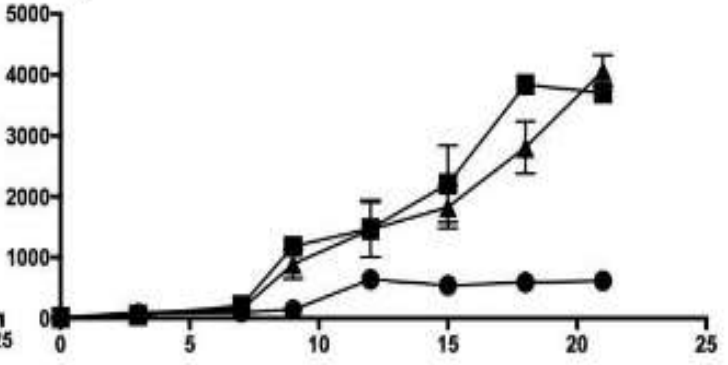

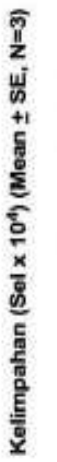

c) $32^{\circ} \mathrm{C}$

d) $34^{\circ} \mathrm{C}$
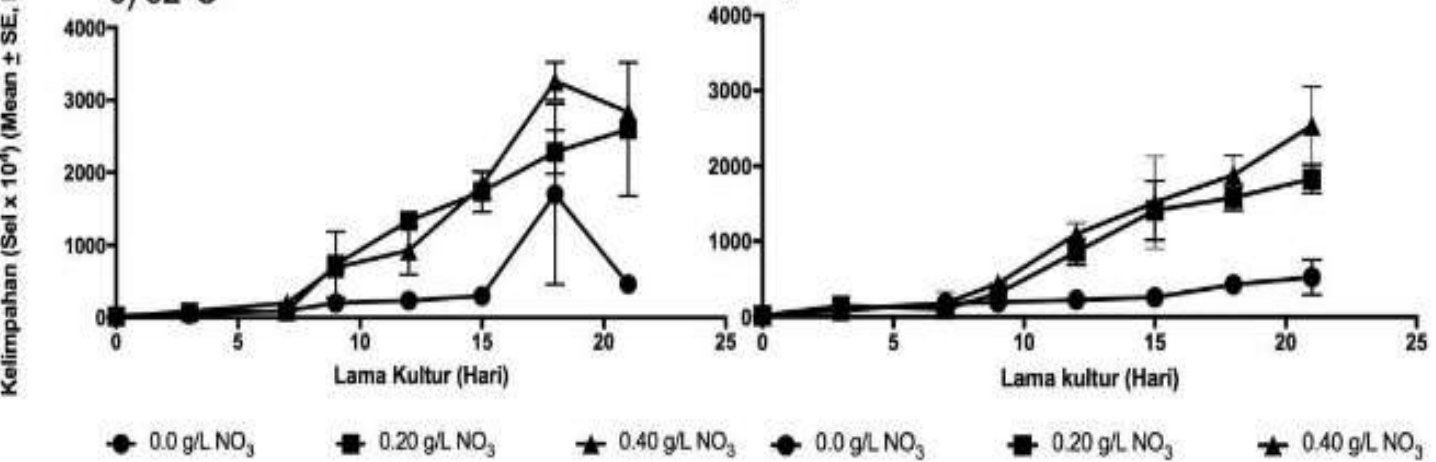

$0.0 \mathrm{glLNO}_{3}$

$0.20 \mathrm{~g} / \mathrm{LNO}$

$0.0 \mathrm{~g} / \mathrm{NO}_{3}$

$0.20 \mathrm{~g} / \mathrm{LNO}$

$0.40 \mathrm{~g} / \mathrm{LNO}_{3}$

Figure 1. Abundance of Melosira sp.. During culture time to treat temperature and nitrate concentration (Mean $\pm \mathrm{SE}, \mathrm{N}=3$ )

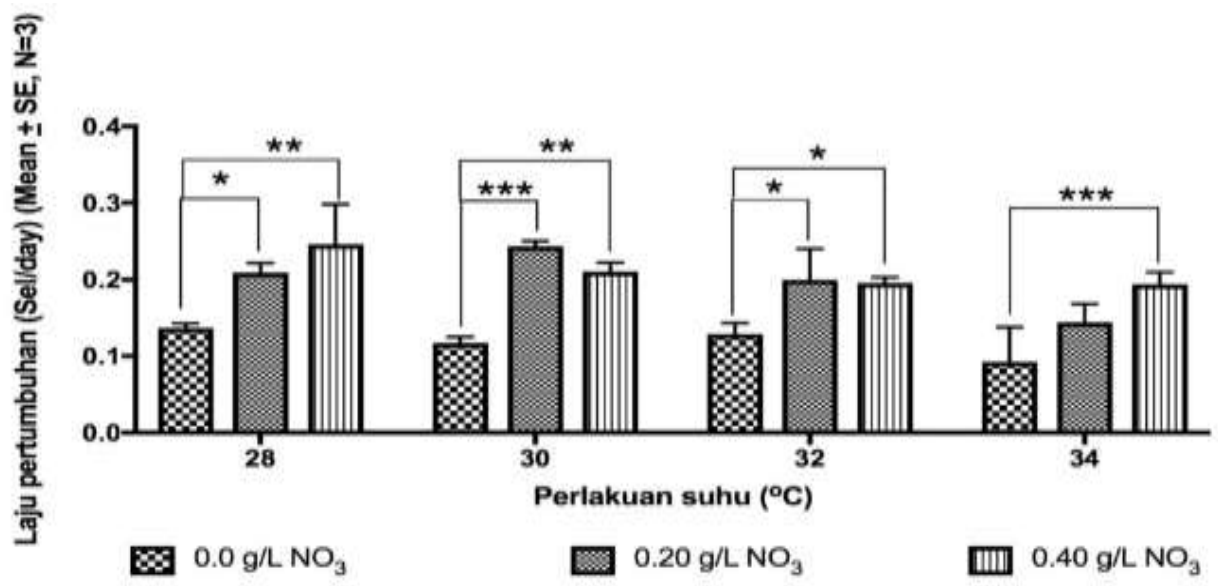

Figure 2. Growth rate of Melosira sp.. at each treatment temperature and nitrate concentration $($ Mean $\pm \mathrm{SE}, \mathrm{N}=3) .{ }^{*}=$ significant difference at $\mathrm{P}<0.05,{ }^{* *}=$ significant difference at $\mathrm{P}<0.05,{ }^{* * *}=$ significant difference at $\mathrm{P}<0.01, \mathrm{~ns}=$ not significantly different 
The effect of increasing temperature and nitrate concentration on biomass, content of C-organic and free fatty acids (ALB) Melosira sp..

The effect of increasing temperature and nitrate concentration on biomass was presented in Figure 3a which showed that there is no clear pattern of the effect of increasing temperature and nitrate concentration on the biomass of Melosira sp.. However, for treating a temperature of $30^{\circ} \mathrm{C}$, an increasing in the concentration of nitrate resulted in an increase in dry weight, on the other hand, at a temperature of $34^{\circ} \mathrm{C}$, the dry weight decreased with increasing nitrate concentration. The results of statistical analysis showed that there was a significant difference in dry weight between $0.0 \mathrm{~g} / \mathrm{L}$ nitrate treatment and $0.40 \mathrm{~g} / \mathrm{L}$ for treatment at $30^{\circ} \mathrm{C}$, for other temperature treatments there was no significant difference in dry weight between treatments of nitrate concentration.

There was a tendency that increasing nitrate concentration caused an increase in the C-organic content of Melosira sp. at each temperature treatment (Figure 3b). The highest C-organic content was found at treatment temperature of $28^{\circ} \mathrm{C}$ and treatment of nitrate concentration $0.20 \mathrm{~g} / \mathrm{L}$ with an average biomass of $0.67 \mathrm{mg} / \mathrm{L}$. While the

lowest dry weight was $0.32 \mathrm{mg} / \mathrm{L}$ which was found at $32^{\circ} \mathrm{C}$ temperature treatment and 0.0 $\mathrm{g} / \mathrm{L}$ nitrate concentration treatment. The results of statistical tests showed that there was a significant difference in the content of Corganic for each temperature treatment between treatments of nitrate concentration.

The percentage of free fatty acids in Melosira sp.. varied between treatment temperatures and nitrate concentrations, however, there was no clear pattern of the impact of increasing temperature and nitrate concentration on the percentage of ALB (Figure 3c). The results of statistical tests showed that there was a significant difference in the percentage of ALB for only a few treatment pairs of temperature and nitrate concentration, including: there was a significant difference in the percentage of ALB between the nitrate concentration of $0.0 \mathrm{~g} / \mathrm{L}$ and $0.20 \mathrm{~g} / \mathrm{L}$ for temperature treatment $32^{\circ} \mathrm{C}$ and $34^{\circ} \mathrm{C}(\mathrm{P}<0.05)$; Between the nitrate concentration of $0.0 \mathrm{~g} / \mathrm{L}$ and $0.40 \mathrm{~g} / \mathrm{L}$ at $30^{\circ} \mathrm{C}$, the ALB percentage was different significantly at the $\mathrm{P}$ test level $<0.05$ and the ALB percentage of Melosira sp.. different significantly between treatment of nitrate concentration $0.20 \mathrm{~g} / \mathrm{L}$ and $0.40 \mathrm{~g} / \mathrm{L}$ at treatment temperature $34^{\circ} \mathrm{C}$ $(\mathrm{P}<0.05)$. 

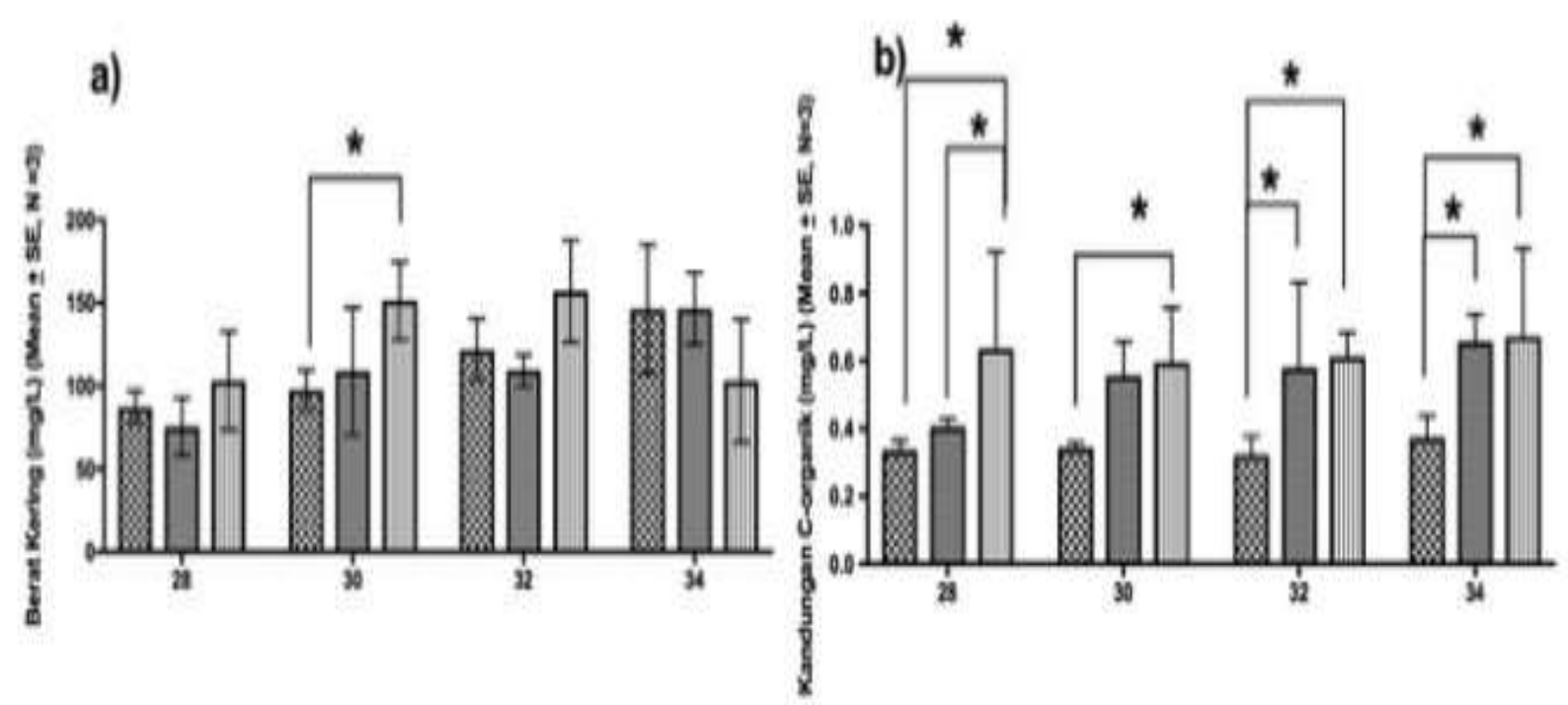

c)

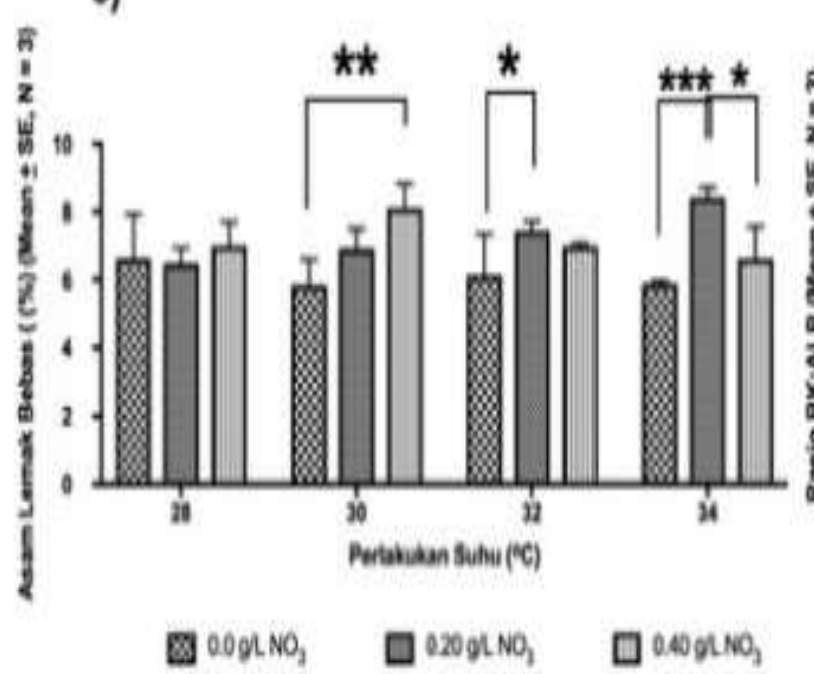

d)

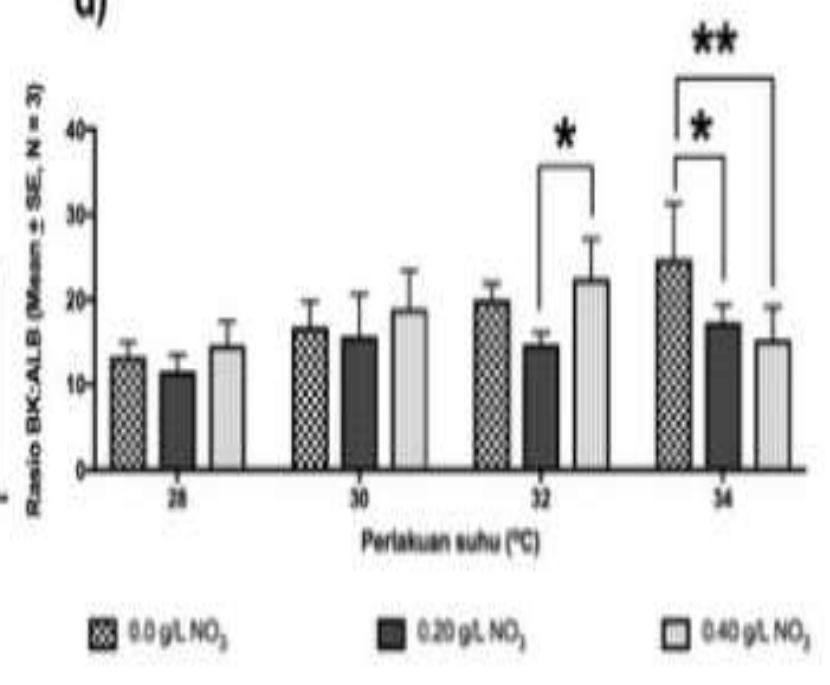

Figure 3. a) Biomass, b) organic $\mathrm{C}$ content, c) free fatty acids Melosira sp.. and d) the ratio of BK to ALB for each treatment temperature and nitrate concentration (Mean $\pm \mathrm{SE}, \mathrm{N}=3$ ). ${ }^{*}=$ significant difference at $\mathrm{P}<0$, and $05,{ }^{* *}=$ significant difference at $\mathrm{P}<0.05 .{ }^{* * *}=$ significant difference at $\mathrm{P}<0.01$

An interesting thing was found in the BK: ALB ratio of Melosira sp.., At a temperature treatment of $34^{\circ} \mathrm{C}, \mathrm{BK}$ : ALB ratio tended to decrease with increasing nitrate concentration (Figure 3d). The highest BK: ALB ratio value was 24.8 for treatment with a temperature of $34^{\circ} \mathrm{C}$ at $0.0 \mathrm{~g} / \mathrm{L}$ nitrate concentration, while the lowest BK: ALB ratio was found at $28^{\circ} \mathrm{C}$ for treatment with a nitrate concentration of 0.20 $\mathrm{g} / \mathrm{L}$ with a value ratio of 11.57 . The results of statistical tests showed that the BK: ALB ratio of Melosira sp.. significantly different between treatment concentrations of nitrate $0.20 \mathrm{~g} / \mathrm{L}$ and $0.40 \mathrm{~g} / \mathrm{L}$ for treatment temperature $32^{\circ} \mathrm{C}$; between treatments, the nitrate concentration 
of $0.0 \mathrm{~g} / \mathrm{L}$ vs $0.20 \mathrm{~g} / \mathrm{L}$ and $0.0 \mathrm{~g} / \mathrm{L}$ vs $0.40 \mathrm{~g} /$

I for the treatment temperature of $34^{\circ} \mathrm{C}$.

\section{CONCLUSION}

The increasing temperature and nitrate concentration had a significant effect on the abundance, growth rate, content of C-organic and free fatty acids of Melosira sp., while an increasing in temperature and nitrate concentration had no significant effect on biomass of Melosira sp.. Increasing temperature tends to decrease the ratio of BK: ALB Melosira sp.. by increasing the nitrate concentration. Further research needs to be done by looking at the metabolic aspects of Melosira $s p$., especially the formation of free fatty acids with an increasing in temperature and nitrate concentration.

\section{ACKNOWLEDGEMENT}

We would like to gratitude to the Ministry of Research, Technology and Higher Education for funding this research with the National Strategy Research scheme for the 2017 Fiscal Year. We would also like to gratitude to the Laboratory of Nutrition, Faculty of Animal Husbandry Unhas which facilitated sample analysis. In addition, unforgettable gratitude to the Research and Development Center for the Sea (Puslitbang Laut), Coastal and Small Islands for providing room for experimentation in this research.

\section{REFERENCES}

Ahmad, I., Fatma, Z., Yazdani, S. S., \& Kumar, S. (2013). DNA barcode and lipid analysis of new marine algae potential for biofuel. Algal Research, 2(1), 10-15. https://doi.org/10.1016/j.algal.2012.10.003

Bondioli, P., Della Bella, L., Rivolta, G., Chini Zittelli, G., Bassi, N., Rodolfi, L.,Tredici, M.R. (2012). Oil production by the marine microalgae Nannochloropsis sp. F\&M-M24 and Tetraselmis suecica F\&M-M33. Bioresource Technology, 114, 567-572. https://doi.org/10.1016/j.biortech.2012.02.123

Boussiba, S., Vonshak, A., Cohen, Z., Avissar, Y., \& Richmond, A. (1987). Lipid and biomass production by the holotolerant microalga Nannochloropsis salina. Biomass, 12, 37-47.

Chisti, Y. (2008). Biodiesel from microalgae beats bioethanol. Trends in Biotechnology, 26(3),126-131.

https://doi.org/10.1016/j.tibtech.2007.12.002

Govoni, C., Morosinotto, T., Giuliano, G., \& Bassi, R. (2006). Exploiting Photosynthesis for Biofuel.

Ketaren, S. (1986), Pengantar Tekhnologi Minyak dan Lemak Pangan, Jakarta. Universitas Indonesia - Press

Lee, O. K., Seong, D. H., Lee, C. G., \& Lee, E. Y. (2015). Sustainable production of liquid biofuels from renewable microalgae biomass. Journal of Industrial and Engineering Chemistry, 29, 24-31. https://doi.org/10.1016/j.jiec.2015.04.016

Li, Y., Horsman, M., Wang, B., Wu, N., \& Lan, C. Q. (2008). Effects of nitrogen sources on cell growth and lipid accumulation of green alga Neochloris oleoabundans. Applied Microbiology and Biotechnology, 81(4), 629636. https://doi.org/10.1007/s00253-0o81681-1

Oo, T. T., Nway, W., Oo, N., Thu, M. K., \& Oo, M. M. (2008). Optimization of Oil-Rich Microalgae (Scenedesmus sp . and Chlorella sp.) Culture for Biodiesel Research and Development. GMSARN International Conference on Sustainable Development: Issues and Prospects for the GMS, 1-3.

Rukminasari, N. (2013). Effect of Temperature and Nutrient Limitation on the Growth and Lipid Content of Three Selected Microalgae 
Rukminasari, N., Omar, S.B.A., \& Lukman, M. Temperature and Nitrate Concentration Effect on The Abundance and Growth Rate of Melosira Sp

(Dunaliella tertiolecta,Nannochloropsis sp. and Scenedesmus sp.) for Biodiesel Production. International Journal of Marine Science, 3(17), 135-144. https://doi.org/10.5376/ijms.2013.03.0017

Rupprecht, J. (2009). From systems biology to fuel-Chlamydomonas reinhardtii as a model for a systems biology approach to improve biohydrogen production. Journal of Biotechnology, 142(1), 10-20. https://doi.org/10.1016/j.jbiotec.2009.02.008 Rusastra, I. W., \& Saliem, H. P. (2010). Krisis Global Pangan-Energi-Finansial: Dampak dan Respon Kebijakan Ketahanan Pangan dan Pengentasan Kemiskinan Food-FuelFinancial Global Crisis : Impact and Policy Response on Security and Poverty Alleviation ketahanan pangan dan kemiskinan regional dan. Analisis Kebijakan Pertanian, 8(1), 29-48.
Sa'adah, A.F., Fauzi, A., dan Juanda, B. (2017). Peramalan Penyediaan dan Konsumsi Bahan Bakar Minyak Indonesia dengan Model Sistem Dinamik. Jurnal Ekonomi dan Pembangunan Indonesia Vol. 17 ( 2), 118-137. http://dx.doi.org/10.21002/jepi.v17i2.661

Sialve, B., Bernet, N., \& Bernard, O. (2009). Anaerobic digestion of microalgae as anecessary step to make microalgal biodiesel sustainable. Biotechnology https://doi.org/10.1016/j.biotechadv.2009.03 .001

Susilaningsih, D., Djohan, AC, \& Widyaningrum, DN (2009). Biodiesel from indigenous Indonesian marine microalgae ,. Journal of Biotechnology Research in Tropical Region, 2 (2), 1-4.

Walker, TL, Purton, S., Becker, DK, \& Collet, C. (2005). Microalgae as bioreactors. Plant Cell Reports, $24 \quad$ (11), 629-641. https://doi.org/10.1007/soo299-005-0004-6. 